\title{
Drought Analysis in Ceyhan Basin Using Standardized Precipitation Index
}

\author{
Muhammed ÇUHADAR ${ }^{1 *}$, Ela ATIŞ ${ }^{2}$
}

\begin{abstract}
Drought is defined as a disaster that affects vital activities negatively due to the decrease in the water supply caused by falling rainfall below normal levels observed over the years. Agricultural drought means that the moisture content in the soil is consistently falling below the climatically appropriate amount, so this directly affects vegetative production and indirectly affects animal production. This study aims to determine dry periods and areas in the Ceyhan Basin by using the Standardized Precipitation Index (SPI). Thus, policies that will reduce the effects of drought will be developed in the regions affected by drought. The SPI has several features that are more advanced than previous indexes, including simplicity and temporal flexibility, and allow for use in all timelines for water resources. The results have shown that the past five years have been dry and the drought has increased over the years, and it is also wiser to grow drought-resistant crops and use pressurized irrigation methods in Afşin and Elbistan, the driest districts of the basin, to improve water efficiency.
\end{abstract}

Key Words: Drought, precipitation, water efficiency, agriculture, SPI

\section{Standart Yağış İndeksi İle Ceyhan Havzasında Kuraklık Analizi}

ÖZET: Kuraklık, yağışların yıllar itibariyle gözlemlenen normal seviyelerinin altına düşmesiyle oluşan su arzında azalma sebebiyle yaşamsal faaliyetleri negatif yönde etkileyen bir afet olarak tanımlanır. Tarımsal kuraklık, topraktaki nem oranının iklimsel olarak uygun miktarın altına sürekli düşmesi, böylece bitkisel üretimi, dolaylı olarak hayvansal üretimi olumsuz etkilemesi anlamına gelir. Bu çalışma, Standart Yağış İndeksi (SPI) yöntemini kullanarak Ceyhan havzasında kurak dönemleri ve bölgeleri belirlemeyi amaçlamaktadır. Böylece kuraklığın etkilerini azaltacak politikalar kuraklıktan etkilenen bölgelerde geliştirilebilecektir. SPI, basitlik ve zamansal esneklik de dahil olmak üzere önceki indekslere göre daha gelişmiş olan ve su kaynakları için tüm zaman çizelgelerinde kullanılmasına izin veren çeşitli özelliklere sahiptir. Elde edilen sonuçlar, havzada son beş yılın kurak geçtiğini, kuraklığın yıllar itibari ile arttığını ve su verimliliğini artırmak için havzada en kurak ilçeler olan Afşin ve Elbistan' da kuraklığa dayanıklı bitki yetiştirmenin ve basınçlı sulama yöntemleri kullanımının daha akıllıca olduğunu göstermektedir.

Anahtar kelimeler: Kuraklık, yağış, su verimliliği, tarım, SPI

\footnotetext{
${ }^{1}$ Muhammed ÇUHADAR (Orcid ID: 0000-0003-0776-5893), Kahramanmaraş Sütçü İmam University, Faculty of Agriculture, Department of Agricultural Economics, Kahramanmaraş Turkey

${ }^{2}$ Ela ATIŞ (Orcid ID: 0000-0001-8011-8102), Ege University, Faculty of Agriculture, Department of Agricultural Economics, Bornova-İzmir, Turkey

*Sorumlu Yazar / Corresponding Author: Muhammed ÇUHADAR,, e-mail: muhammedcuhadar@gmail.com

This study is a part of Muhammed ÇUHADAR's PhD thesis. The study was presented as a summary paper at the 1st International GAP Agriculture and Livestock Congress held on 26 April 2018 in Şanliurfa.
}

Geliş tarihi / Received: 25.03.2019

Kabul tarihi / Accepted: 27.07.2019 


\section{INTRODUCTION}

Drought is one of the most important natural disasters that cause billions of dollars of loss every year in agriculture (Narasimhan and Srinivasan, 2005). Drought is defined as a disaster that affects vital activities in the negative direction due to the decrease in the water supply caused by falling rainfall below normal levels observed over the years (Kapluhan, 2013). Meteorological drought begins before the hydrological and agricultural drought. Therefore, the occurrence of prolonged and severe hydrological and agricultural droughts can be directly attributed to a meteorological drought. As rainfall variability in arid and semi-arid climate regions is very high, drought events in these climatic regions may cause greater ecological/economic losses (Ilgar, 2010).

Assessment based on the severity and duration of disasters, total economic loss, social impact, and durability; the drought event took place in the first place in 31 kinds of natural disasters that are effective in the world according to their importance. The uncertainty of the beginning and the end of the drought, increasing cumulatively, the impact on more than one source at the same time and the high economic size are the most important features that distinguish it from other natural disasters (Ilgar, 2010).

Drought, which can occur in all climates and cause great socioeconomic losses afterward, has attracted much more attention recently by scientists and decision makers (Li et al., 2016). Also, drought is expected to be more frequent and harsh with limited and uncertain water supply due to raised water demand from population growth and climate change and variability (Kim et al., 2015). Drought usually occurs by falling below the average amount of rainfall and the first sector to be affected by drought is agriculture due to its dependence on water resources and soil nutrient reserves at various stages of plant growth (Narasimhan and Srinivasan, 2005). At the same time, the agricultural sector is the one that will provide the most significant benefit from the development of decisions that support reducing the effects of drought, the development of early warning and drought surveillance systems in the environment and society (Merkoci et al., 2013).

The effects of the drought are first seen in the form of reduced soil moisture and high evaporation in agriculture. The drought has always had more severe consequences for agricultural communities compared to nonagricultural societies. Rural economies are mostly dependent on agriculture in most of the developing countries, and agriculture is mainly reliant on rainfall. Drought can cause both surface and underground water resources to be scarce and have catastrophic effects on breeding livestock products and crop production (Ashraf and Routray, 2013). Agricultural drought means that the moisture content in the soil is continually falling below the climatically appropriate amount, so this directly affects vegetative production and indirectly affects animal production in a negative way (Quiring and Papakryiakou, 2003). Measures against the drought need to be considered before a drought occurs. These measures should be enough to remove the long-term effects of drought (Keskiner et al., 2016). It is necessary to determine the dangerous areas for drought and to carry out some activities to remove the destructive actions of the drought in these regions.

Drought is an essential natural event that has been studied seriously by many researchers for many years. However, the fact underlying the difficulties encountered in the study of such events is the inability to reach a definite knowledge of when the drought will begin, how long, how severe it will be, and the size of the area under its influence (Gümüş et al., 2016). According to the survey results that the World Meteorological Organization has conducted in 87 countries, 74 countries including Turkey were determined that are the most affected by drought (Ilgar, 2010). Although studies on drought risk assessment -which aim to assess drought 
vulnerability and monitor it- are still inadequate in Turkey, there has been an increase in droughtrelated studies in recent years as global warming has come to the fore (Reis and Dutal, 2016).

Several reports agree on the Mediterranean Basin as the region most affected by climate change (Aksoy and Can, 2012). According to regional climate projections made by the Turkish State Meteorological Service, Turkey has experienced one of the significant declines in rainfall in the Mediterranean Region (Republic of Turkey Ministry of Environment and Urbanization, 2016). According to these projections, the Mediterranean Region is among the regions where the lack of rainfall will be felt most in the 2015-2040 period. From 2041 through 2070, the Mediterranean Region is among the areas facing drought mostly. The Ceyhan basin is located in the Mediterranean Region. The fact that the Ceyhan Basin is situated in this critical region necessitates the analysis of climate and droughtrelated to this basin.

The purpose of this study is to perform drought analysis and to determine arid years and regions in the Ceyhan Basin by using the SPI method. Thus, policies that reduce the effects of drought were developed in the regions affected by drought. The Ceyhan basin is also an essential region for agricultural production. One of the most significant lowlands of Turkey is located on this region (Elbistan Lowland). Decreases in agricultural output in the case of drought will adversely affect the regional economy. It is necessary to determine the dangerous areas regarding dryness and carry out activities that eliminate the effects of drought in these regions in the basin.

For this purpose, the following questions were created to find solutions and develop policies:

- Which years were dry in the basin?

- Is the drought in recent years more than the previous ones?
- Does drought in the basin tend to increase from the past to the present?

- Which regions have been arid in the basin?

- Does drought tend to increase in dry and wet regions?

- What measures can be made to reduce the effects of drought in arid regions?

\section{MATERIAL and METHOD}

There are various methods to study temporal and spatial drought conditions. The Aridity Index (AI) method is a climatic index useful for recording the development of the drought phenomenon. Potential evaporation data is required to calculate with this index (Nastos et al., 2013). Another method, the Percent of Normal Index (PNI), is known as the most straightforward drought index and is obtained by dividing the amount of rainfall at a given time interval by the average. Precipitation of 12 months or less can also be used in PNI calculations (Şimşek and Çakmak, 2010). Another method used in drought analysis is the Erinç Aridity Index (I-m), which is based on the average maximum temperature ratio, which is assumed to be caused by rainfall and evaporation deficit (Erinç, 1965; Türkeş, 2005). Palmer Drought Severity Index (PDSI) was created by Palmer (1965) to measure the cumulative dissipation of atmospheric moisture supply and demand in the surface. PDSI transforms past years' rainfall, humidity supply, and humidity demand into a hydrological calculation system (Dai et al., 2004). The PDSI is based on a primitive water balance rather than entirely rainfall-based (Wells et al., 2004).

\section{Standardized Precipitation Index (SPI)}

In this study, the Standardized Precipitation Index (SPI) method was used to analyze temporal and spatial drought in the Ceyhan Basin. The SPI has several features that are more advanced than previous indexes, including simplicity and temporal flexibility, and allows for use in all timelines for water resources. The only 
meteorological variable needed in this method is rainfall. The most important advantage is that different time scales can be used to determine the effect of drought on underground and surface water resources and agricultural activities due to lack of rainfall. At least 30 years of rainfall records are used in this method. The precipitation time series is calculated as monthly rainfall. The SPI is obtained by dividing the difference of rainfall from average into standard deviations within the specified period $(1,3,6,9,12,24$ months) (Yetmen, 2013).

The Standardized Precipitation Index method, which transforms the rainfall parameter into a single numerical value to define the drought of regions with different climates, is described by Mckee et al. (1993). The SPI is obtained by dividing the difference of rainfall from average into standard deviations over a selected period, and is calculated as:

$S Y I_{i j}=\frac{X i j-\mu j}{\sigma j}$.

In this equation: $\mathrm{Xij}$ is the rainfall values observed in a " $\mathrm{j}$ " month; $\mu \mathrm{j}$ is the expected value of the rainfall series in the " $\mathrm{j}$ " months; $\sigma \mathrm{j}$ indicates the standard deviation of the set (Keskiner, 2016). The drought classification according to the SPI is as follows (Table 1).

Table 1. Index values and classification according to the SPI method

\begin{tabular}{ll}
\hline SPI Index values & Drought Category \\
\hline 2.0 and above & Extremely wet \\
1.50 to 1.99 & Very wet \\
1.00 to 1.49 & Moderately wet \\
0 to 0,99 & Mildly wet \\
-0.99 to 0 & Mildly dry \\
-1.00 to -1.50 & Moderately dry \\
-1.50 to -1.99 & Severely dry \\
-2.0 and below & Extremely dry \\
\hline
\end{tabular}

Mckee et al., 1993.

\section{Study Area}

Ceyhan Basin is one of the 25 river basins in Turkey. The Ceyhan Basin, consisting of wide alluvial sand and steep mountainous terrain, goes into the interior of Central Anatolia from the Gulf of Iskenderun. Almost all of Kahramanmaraş and Osmaniye Provinces; Ceyhan and Yumurtalık Districts and a part of Yüreğir District and Kozan Districts of Adana Province are located within the boundaries of Ceyhan Basin. The Ceyhan River is born in Pınarbaşı location of Elbistan District and flows into the Gulf of Iskenderun (TÜBITTAK, 2010). Figure 1 shows the location of the Ceyhan Basin.

\section{Rainfall Data}

A minimum of 30 years' rainfall data is required to perform drought analysis with the SPI method. For this reason, to investigate the drought situation of the Ceyhan Basin, rainfall data of 1986-2017 of the precipitation stations belonging to the basin were taken from the Turkish State Meteorological Service. There are nine stations in the basin where rainfall recordings are available at least in the last 30 years. These stations were determined as Kahramanmaraş, Elbistan, Afşin, Göksun, Osmaniye, Ceyhan, Kozan, Yumurtalık and Gölbaş1. The locations of the stations of which rainfall data were received are as follows (Figure 1).

The following table shows the average, maximum and minimum annual and monthly rainfall of the locations in the Ceyhan Basin between 1986-2017 (Table 2). 


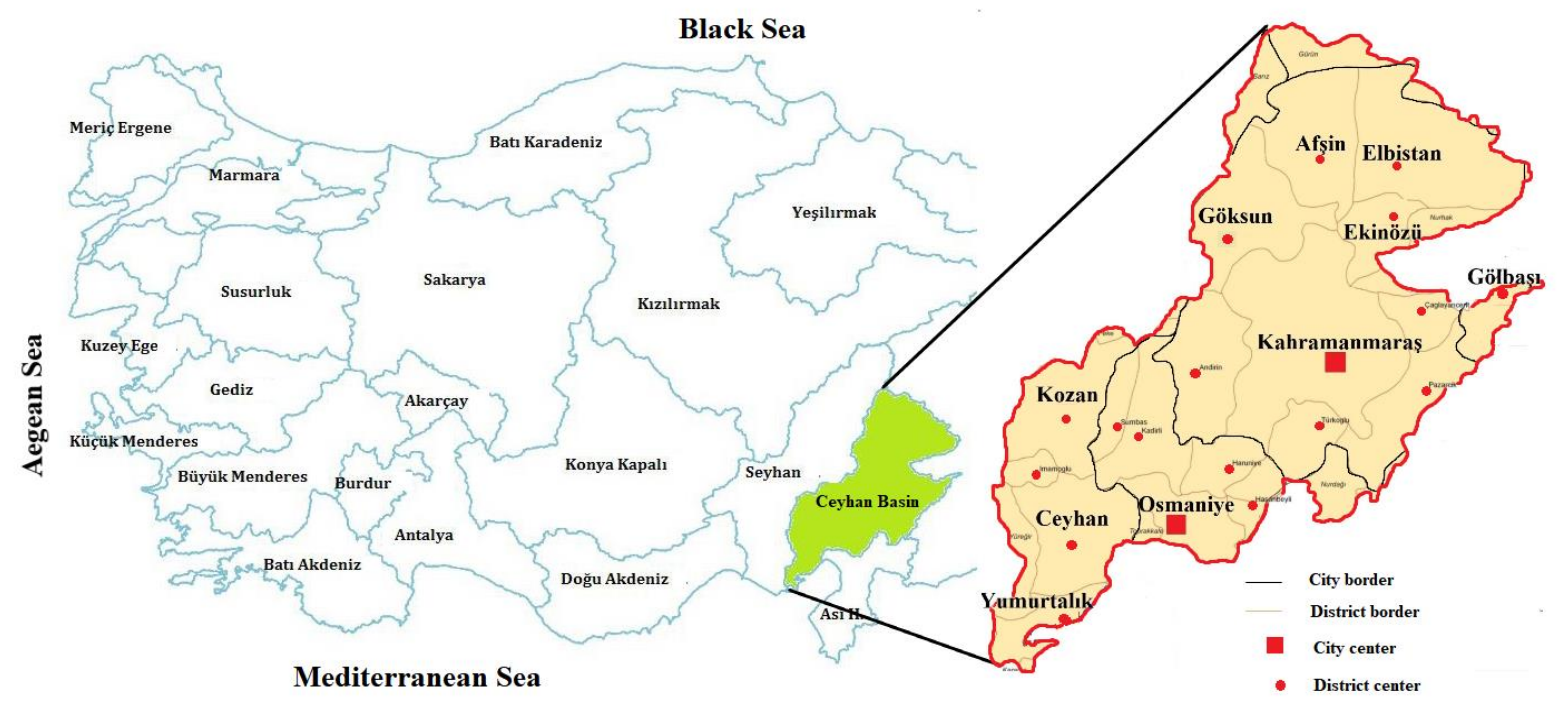

Figure 1. The location of the Ceyhan Basin

Source: Republic of Turkey Ministry of Agriculture and Forestry, 2016; TÜBİTAK, 2010)

Table 2. The rainfall data of the locations in the Ceyhan Basin

\begin{tabular}{|c|c|c|c|c|c|c|c|}
\hline Locations & $\begin{array}{c}\text { Average } \\
\text { annual } \\
\text { rainfall } \\
(\mathbf{m m})\end{array}$ & $\begin{array}{c}\text { Standard } \\
\text { deviation } \\
\text { (annual) }\end{array}$ & $\begin{array}{c}\text { Annual } \\
\text { minimum } \\
\text { rainfall } \\
(\mathbf{m m})\end{array}$ & $\begin{array}{c}\text { Annual } \\
\text { maximum } \\
\text { rainfall }(\mathbf{m m})\end{array}$ & $\begin{array}{c}\text { Average } \\
\text { monthly } \\
\text { rainfall } \\
(\mathbf{m m})\end{array}$ & $\begin{array}{c}\text { Monthly } \\
\text { minimum } \\
\text { rainfall } \\
(\mathbf{m m})\end{array}$ & $\begin{array}{c}\text { Monthly } \\
\text { maximum } \\
\text { rainfall } \\
(\mathbf{m m})\end{array}$ \\
\hline Osmaniye & 805.77 & 183.83 & 492,50 & 1230,90 & 67,15 & 0,00 & 331,40 \\
\hline Kozan & 804.05 & 152.61 & 560,50 & 1176,80 & 67,00 & 0,00 & 296,00 \\
\hline Yumurtalık & 794.03 & 215.65 & 439,60 & 1334,80 & 66,17 & 0,00 & 476,10 \\
\hline Gölbaşı & 722.40 & 148.35 & 408,60 & 1107,60 & 60,20 & 0,00 & 366,60 \\
\hline Kahramanmaraş & 722.05 & 167.92 & 442,70 & 1169,00 & 60,17 & 0,00 & 317,00 \\
\hline Ceyhan & 710.16 & 162.20 & 437,60 & 1019,00 & 59,18 & 0,00 & 422,20 \\
\hline Göksun & 559.20 & 150.43 & 181,60 & 881,00 & 46,60 & 0,00 & 233,00 \\
\hline Afşin & 415.03 & 78.82 & 262,40 & 563,50 & 34,59 & 0,00 & 155,10 \\
\hline Elbistan & 385.68 & 70.03 & 223,10 & 534,40 & 32,14 & 0,00 & 146,60 \\
\hline Ceyhan Basin & 657.60 & 116.05 & 444,36 & 849,31 & 54,80 & 0,00 & 218,53 \\
\hline
\end{tabular}

Source: Turkish State Meteorological Service, 2018.

\section{RESULTS and DISCUSSION}

According to the SPI calculation done with the rainfall data taken from the Turkish State Meteorological Service, the numbers and percentage of wet and dry years in the Ceyhan Basin are listed in the table below. According to the table, in the period between 1986 and 2017, two years were severely dry, five years were moderately dry and nine years were mildly dry. The probability of a year to be severely dry is \%6.3. In the calculations made in six-month periods, in the basin, two periods were extremely dry, three were severely dry, two were moderately dry and 24 periods were mildly dry. The probability of a period to be extremely dry is \%3.1. In the calculations made in three-month periods, in the basin, it was reached that six periods were severely dry, 16 were moderately dry, and 44 were slightly dry. The probability of a period to be severely dry is \%4.7. In the calculations made on a monthly basis, it was reached that in the basin while there was one month of extremely dry, there were six months of severely dry, 46 of moderately dry and 169 of slightly dry. The probability of a month to be moderately dry is \%12.0 (Table 3 ).

Table 4 shows wet and dry years between 1986 and 2017 in the basin. According to the 
results, it is determined that the year 2013 was severely dry, the years 2016 and 2014 were moderately dry, and the years 2015 and 2017 were mildly dry. These results show that five years' drought was experienced in the basin from 2013 to 2017.
When we examine the trends of the Standardized Precipitation Index values between 1986 and 2017 by years, it is noteworthy that the trend line is downward. This result shows us that the drought in the Ceyhan Basin has increased for the past 32 years (Figure 2).

Table 3. Ceyhan Basin annual, six-month, three-month and monthly drought classification

\begin{tabular}{lcccccccc}
\hline & \multicolumn{2}{c}{ Annual periods } & \multicolumn{2}{c}{ Six-month periods } & \multicolumn{2}{c}{ Three-month periods } & \multicolumn{2}{c}{ Monthly periods } \\
\hline Classification & Periods & \% & Periods & \% & Periods & \% & Periods & \% \\
\hline Extremely wet & - & - & 1 & 1.6 & 3 & 2.3 & 15 & 3.9 \\
Very wet & 2 & 6.3 & 3 & 4.7 & 5 & 3.9 & 25 & 6.5 \\
Moderately wet & 4 & 12.5 & 8 & 12.5 & 19 & 18.8 & 26 & 6.8 \\
Mildly wet & 10 & 31.3 & 21 & 32.8 & 35 & 27.3 & 96 & 25.0 \\
\hline Mildly dry & 9 & 28.1 & 24 & 37.5 & 44 & 34.4 & 169 & 44.0 \\
Moderately dry & 5 & 15.6 & 2 & 3.1 & 16 & 12.5 & 46 & 12.0 \\
Severely dry & 2 & 6.3 & 3 & 4.7 & 6 & 4.7 & 6 & 1.6 \\
Extremely dry & - & - & 2 & 3.1 & - & - & 1 & 0.3 \\
\hline Total & 32 & 100.0 & 64 & 100.0 & 128 & 100.0 & 384 & 100.0 \\
\hline
\end{tabular}

Table 4. Dry and wet years in the basin

\begin{tabular}{llll}
\hline Years & Classification & Years & Classification \\
\hline 2013 & Severely dry & $\mathbf{2 0 1 2}$ & Mildly wet \\
$\mathbf{1 9 9 3}$ & Severely dry & $\mathbf{2 0 1 1}$ & Mildly wet \\
$\mathbf{2 0 1 6}$ & Moderately dry & $\mathbf{2 0 1 0}$ & Mildly wet \\
$\mathbf{2 0 1 4}$ & Moderately dry & $\mathbf{2 0 0 1}$ & Mildly wet \\
$\mathbf{1 9 9 9}$ & Moderately dry & $\mathbf{2 0 0 0}$ & Mildly wet \\
1990 & Moderately dry & $\mathbf{1 9 9 8}$ & Mildly wet \\
1989 & Moderately dry & $\mathbf{1 9 9 7}$ & Mildly wet \\
$\mathbf{2 0 1 7}$ & Mildly dry & $\mathbf{1 9 9 5}$ & Mildly wet \\
$\mathbf{2 0 1 5}$ & Mildly dry & $\mathbf{1 9 9 4}$ & Mildly wet \\
$\mathbf{2 0 0 8}$ & Mildly dry & $\mathbf{1 9 8 6}$ & Mildly wet \\
$\mathbf{2 0 0 7}$ & Mildly dry & $\mathbf{2 0 0 3}$ & Moderately wet \\
$\mathbf{2 0 0 6}$ & Mildly dry & $\mathbf{1 9 9 6}$ & Moderately wet \\
2005 & Mildly dry & $\mathbf{1 9 9 1}$ & Moderately wet \\
$\mathbf{2 0 0 4}$ & Mildly dry & $\mathbf{1 9 8 7}$ & Moderately wet \\
$\mathbf{2 0 0 2}$ & Mildly dry & $\mathbf{2 0 0 9}$ & Very wet \\
$\mathbf{1 9 9 2}$ & Mildly dry & $\mathbf{1 9 8 8}$ & Very wet \\
\hline
\end{tabular}

In the calculations made using the 32-year rainfall data (1986-2017) in the Ceyhan Basin, the years are divided into two periods, the first 16 and the last 16 . While $31.25 \%$ of the first 16 year period is dry, this ratio is $68.75 \%$ in the last 16 -year period. This result clearly shows that the drought in the basin is increasing and now it is more likely to experience dry years than before (Table 5).
When the drought situation of the locations in the Ceyhan Basin is examined by using the average rainfall data of the basin, only three mildly dry years have been experienced in the Kozan District for the last 32 years. On the other hand, any wet year has not been experienced in the districts of Afşin and Elbistan in the same period. Afşin and Elbistan are determined as the locations experiencing the drought mostly (Table 6). 


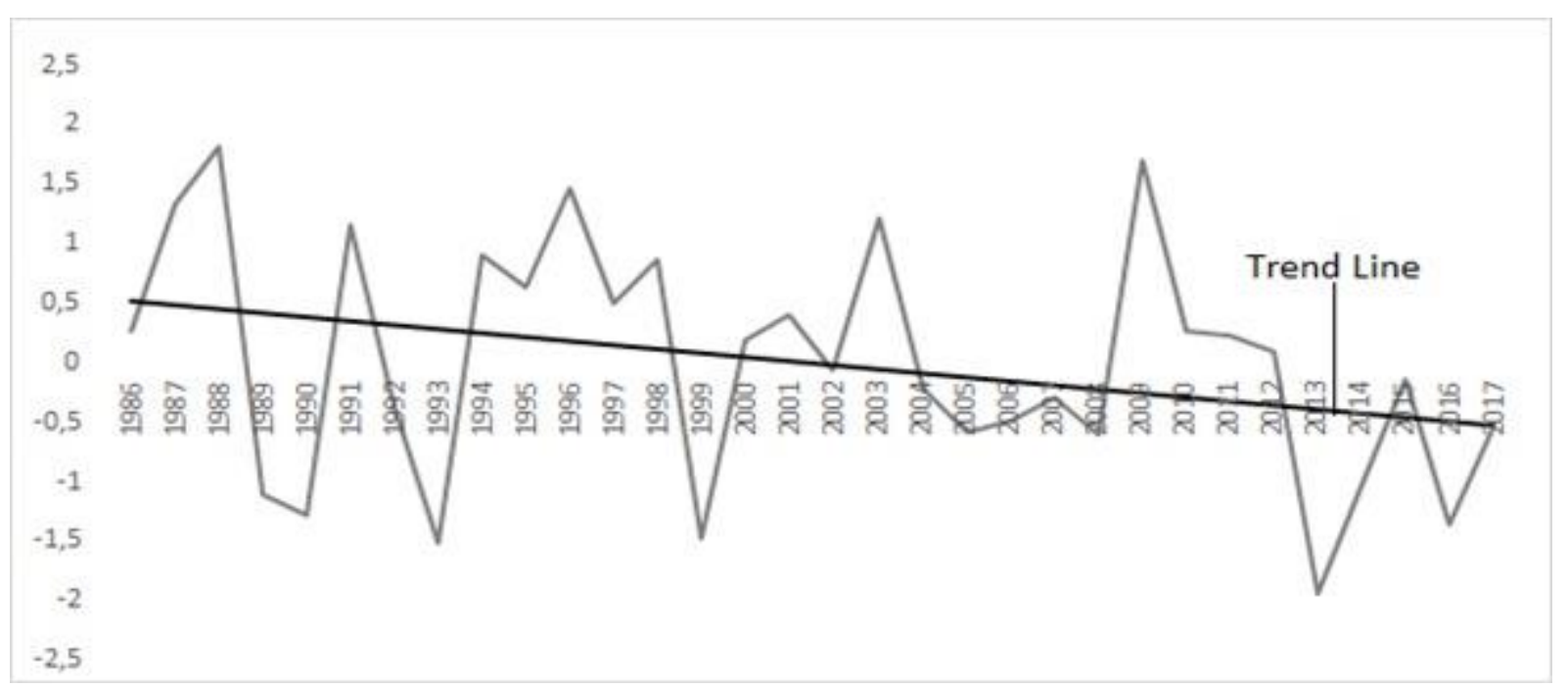

Figure 2. The line chart of SPI index values of the basin by years

Table 5. Annual drought comparison between the periods of 1986-2001 and 2002-2017

\begin{tabular}{|c|c|c|c|c|c|c|}
\hline & \multicolumn{3}{|c|}{ 1986-2001 } & \multicolumn{3}{|c|}{ 2002-2017 } \\
\hline Classification & Number of years & & Percentage & Number of years & & Percentage \\
\hline Extremely wet & - & \multirow{4}{*}{$\begin{array}{l}\tilde{D}^{0} \\
\tilde{E}_{0}^{0} \\
3\end{array}$} & \multirow{4}{*}{68.75} & - & \multirow{4}{*}{ 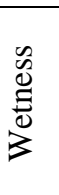 } & \multirow{4}{*}{31.25} \\
\hline Very wet & 1 & & & 1 & & \\
\hline Moderately wet & 3 & & & - & & \\
\hline Mildly wet & 7 & & & 4 & & \\
\hline Mildly dry & 1 & \multirow{4}{*}{$\begin{array}{l}\overrightarrow{\vec{z}} \\
\text { oD } \\
\overrightarrow{0} \\
\overrightarrow{0}\end{array}$} & \multirow{4}{*}{31.25} & 8 & \multirow{4}{*}{$\begin{array}{l}\overrightarrow{\vec{b}} \\
\overrightarrow{00} \\
\overrightarrow{0} \\
\overrightarrow{0}\end{array}$} & \multirow{4}{*}{68.75} \\
\hline Moderately dry & 3 & & & 1 & & \\
\hline Severely dry & 1 & & & 2 & & \\
\hline Extremely dry & - & & & - & & \\
\hline Total & 16 & & 100.0 & 16 & & 100.0 \\
\hline
\end{tabular}

Table 6. Number of dry and wet years of the locations in Ceyhan Basin

\begin{tabular}{lccccccccc}
\hline Classification & Kozan & Yumurtalık & Osmaniye & K.Maraş & Gölbaşı & Ceyhan & Göksun & Afşin & Elbistan \\
\hline Extremely wet & 3 & 4 & 3 & 1 & 1 & - & - & - & - \\
Very wet & 3 & 2 & 1 & 2 & 1 & 2 & - & - & - \\
Moderately wet & 6 & 7 & 6 & 4 & 1 & 4 & 1 & - & - \\
Mildly wet & 17 & 12 & 15 & 16 & 18 & 15 & 9 & - & - \\
\hline Mildly dry & 3 & 7 & 7 & 9 & 11 & 11 & 17 & 17 & 11 \\
Moderately dry & - & - & - & - & 1 & - & 3 & 14 & 18 \\
Severely dry & - & - & - & - & - & - & 1 & 1 & 3 \\
Extremely dry & - & - & - & - & 1 & - & 1 & - & - \\
\hline Total & 32 & 32 & 32 & 32 & 32 & 32 & 32 & 32 & 32 \\
\hline
\end{tabular}

The following graph shows the lines of the SPI values of Afşin and Elbistan where the drought is experienced mostly. Besides being dry in Afşin and Elbistan, it is determined that the drought level is also rising. As it is seen, the trend line for Afşin and Elbistan is downward, and the decrease in the SPI values shows that drought increases. The trend line is downward not only for Afşin and Elbistan but also for all other locations except Gölbaşı. It means that we can make a mention of a decrease in precipitation and an increase in drought in these locations (Figure 3). 

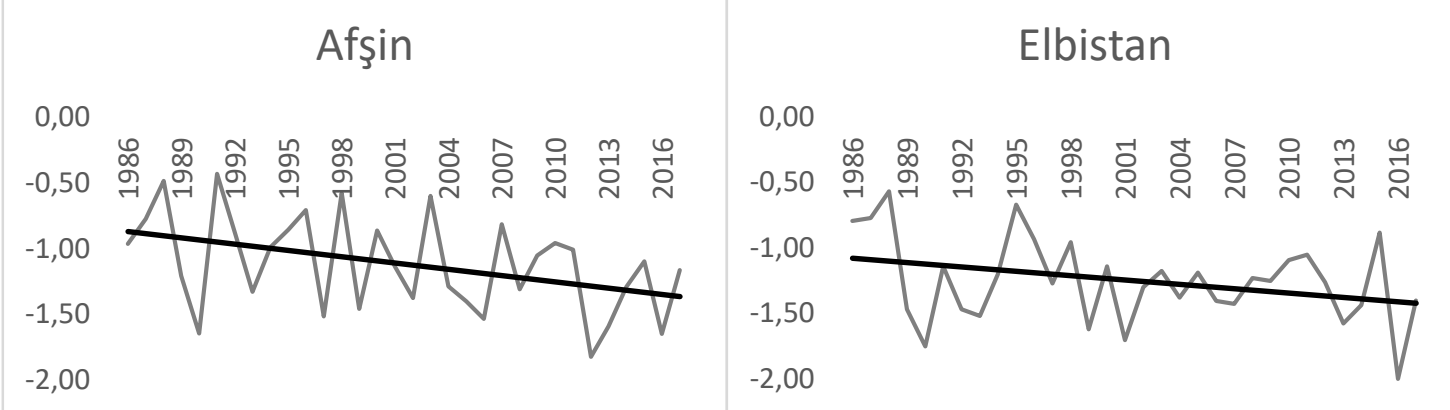

Figure 3. The line chart of SPI index values of Afşin and Elbistan by years

\section{CONCLUSIONS}

As a result of the calculations made according to the SPI method, two years in the Ceyhan Basin were severely dry, five years were moderately dry and nine years were mildly dry. Besides, it is found that 2013 was severely dry, 2016 and 2014 were moderately dry, and 2015 and 2017 were mildly dry. These results show that the last five years in the basin were dry. When the Standard Precipitation Index values between 1986 and 2017 are shown with a line graph, and a trend line is added, it is concluded that this trend line is downward and this means that the drought situation is increasing in the basin.

The index values obtained from 32 years' data taken from the Turkish State Meteorological Service are divided into two periods as the first 16 years and the last 16 years. As a result of this division, in the last 16 years' period, there were much less wet years and much more dry years than in the first 16 years' period. This result means that the basin is now drier than in the past. Calculations based on annual periods in the basin showed that the probability of a period to be severely dry is $6.3 \%$, and moderately dry is $15.6 \%$. Calculations based on six-month periods in the basin showed that the probability of a period to be extremely dry is $3.1 \%$, and severely dry is $4.7 \%$. Calculations based on three-month periods in the basin showed that the probability of a period to be severely dry is $4.7 \%$, and moderately dry is $12.5 \%$. Calculations based on monthly periods in the basin showed that the probability of a period to be extremely dry is
$0.3 \%$, severely dry is $1.6 \%$, and moderately dry is $12.0 \%$.

In the SPI calculation for Ceyhan Basin, any wet years in the districts of Afşin and Elbistan has not been experienced while only three dry years in Kozan District have been experienced for the last 32 years. Besides, just seven years in Osmaniye Province and Yumurtalık District were mildly dry and in Göksun District, nine years were mildly wet and a year was moderately wet. Moreover, drought has increased in almost all locations for the last 32 years.

From all these results, it can be said that drought is a natural phenomenon and will start to be seen more frequently with the effect of global climate change. If the water resources of the Ceyhan Basin are not managed well during both wet and dry periods, the drought will become a chronic problem and its effects will be inescapable one day in the not-so-distant future. Drought is a dangerous natural disaster that causes severe problems regarding living life. We cannot eliminate the problems caused by drought, but it is possible to reduce the adverse effects of drought. One of the most important ways to combat dryness is the precaution of drought.

One of the measures that can be taken to reduce the effects of drought will be to provide financial support by the government for droughtresistant crops in the regions with high drought tendency. These regions are seen as Afşin and Elbistan districts in Ceyhan Basin. In these districts, it would be wisely to focus on droughtresistant products in agriculture. Another measure 
is to use water efficiency enhancing systems. By using pressurized irrigation methods, it will be possible to increase water efficiency and crop yield in areas with water constraints. Financial support can also be provided for installing pressurized irrigation systems to increase the usage of these methods. If any support is provided for installing these systems, the amount of support can be raised, and bureaucratic procedures can be softened.

\section{ACKNOWLEDGEMENT}

This study is a part of the doctoral thesis of Muhammed ÇUHADAR and was presented as an abstract in the $1^{\text {st }}$ International GAP Agriculture and Livestock Congress in Şanlıurfa, Turkey.

\section{REFERENCES}

Aksoy U, Can HZ, 2012. Expected effects of climate change on organic agriculture in Turkey. New Medit, A Mediterranean Journal of Economics, Agricultural and Environment, 11(4 SI): 3-10.

Ashraf M, Routray JK, 2013. Perception and understanding of drought and coping strategies of farming households in northwest Balochistan. International Journal of Disaster Risk Reduction, 5: 49-60.

Dai A, Trenberth KE, Qian T, 2004. A global dataset of Palmer Drought Severity Index for 1870-2002: relationship with soil moisture and effects of surface warming. Journal of Hydrometeorology, 5(6): 11171130.

Erinç S, 1965. Yağış Müessiriyeti Üzerine Bir Deneme ve Yeni Bir İndis. İstanbul University, Geography Institute Publications, No: 41, İstanbul.

Gümüş V, Başak A, Oruç N, 2016. Drought Analysis of Şanlıurfa Station with Standard Precipitation Index (SPI). Harran University, Journal of Engineering, 1(1): 36-44.
Ilgar R, 2010. Drought Status and Trends in the Dardanelles and the Standardized Precipitation Index Determination. Marmara Geographical Review, 22: 183204.

Iş1ldar M, 2010. Investigation of Changes in Corn Yield with Agricultural Drought Indices in Some Provinces of Aegean Region. (Master's thesis, Adnan Menderes University, Graduate School of Natural and Applied Sciences). 92 p.

Kapluhan E, 2013. Drought and drought in Turkey effect of agriculture. Marmara Geographical Review, 27: 487-510.

Keskiner AD, Çetin M, Uçan M, Şimşek M, 2016. Meteorological Drought Analysis with Different Return Periods by Using Standardized Precipitation Index in Geographic Information Systems Environment: A Case Study in The Seyhan River Basin. Çukurova University, Faculty of Agriculture, Çukurova Journal of Agriculture and Food Sciences, 31(2): 7990.

Kim H, Park J, Yoo J, Kim TW, 2015. Assessment of drought hazard, vulnerability, and risk: a case study for administrative districts in South Korea. Journal of Hydro-environment Research, 9(1): 28-35.

Li Z, Hao Z, Shi X, Déry SJ, Li J, Chen S, Li, Y, 2016. An agricultural drought index to incorporate the irrigation process and reservoir operations: A case study in the Tarim River Basin. Global and Planetary Change, 143: 10-20.

McKee TB, Doesken NJ, Kleist J, 1995. Drought monitoring with multiple time scales. In Proceedings of the 9th Conference on Applied Climatology. Dallas, Boston, MA: American Meteorological Society, 233236. 
McKee TB, Doesken NJ, Kleist J, 1993. The relationship of drought frequency and duration to time scales. In Proceedings of the 8th Conference on Applied Climatology. Boston, MA: American Meteorological Society, 179-183.

Merkoci AL, Mustaqi V, Mucaj L, Dvorani M, 2013. Arnavutluk Bölgesinde Kuraklik ve Standart Yağiş İndeksinin (SPI) Kullanimi. Journal of the Faculty of Engineering \& Architecture of Gazi University, 28(1): 161-166

Narasimhan B, Srinivasan R, 2005. Development and evaluation of soil moisture deficit index (SMDI) and evapotranspiration deficit index (ETDI) for agricultural drought monitoring. Agricultural and Forest Meteorology, 133(1): 69-88.

Nastos PT, Politi N, Kapsomenakis J, 2013. Spatial and temporal variability of the aridity index in Greece. Atmospheric Research, 119: 140-152.

Quiring SM, Papakryiakou TN, 2003. An evaluation of agricultural drought indices for the Canadian prairies. Agricultural and Forest Meteorology, 118(1): 49-62.

Reis M, Dutal H, 2016. Determining hydrological drought probability in future using markov chain model for Kahramanmaras city. Kastamonu University, Journal of Forestry Faculty, 16(1): 34-43.

Seçkin N, Topçu E, 2016. Drought Analysis of the Seyhan Basin by Using Standardized Precipitation Index (SPI) and L-moments Journal of Agricultural Sciences., 22(2): 196-215.
Şimşek O, Çakmak B, 2010. Drought analysis for 2007-2008 agricultural year of Turkey. JOTAF/ Journal of Tekirdag Agriculture Faculty, 7(3): 99-109.

Republic of Turkey Ministry of Agriculture and Forestry, 2016. Impacts of Climate Change on Water Resources., Final Report, Ceyhan Basin, General Directorate of Water Management, Ankara.

Republic of Turkey Ministry of Environment and Urbanization, 2016. 6th National Communication on Climate Change, Directorate General of Environmental Management, Ankara.

TÜBİTAK 2010. Preparation of Basin Protection Action Plans -Ceyhan Basin, Final Report, The Scientific and Technological Research Council of Turkey, Marmara Research Center, Environment and Cleaner Production Institute. Gebze, Kocaeli.

Türkeş M, 2005. Climate of southern part of the Middle Kizılirmak Sub-Region (Cappadocia District) and its vulnerability to desertification. Aegean Geographical Journal, 14(1-2): 73-97

Wells N, Goddard S, Hayes MJ, 2004. A selfalibrating Palmer drought severity index. ournal of Climate, 17(12): 2335-2351.

Yetmen H, 2013. Van Gölü Havzası'nın Kuraklık Analizi. Education and Society in the $21^{\text {st }}$ Century, 2(5):184-198. 